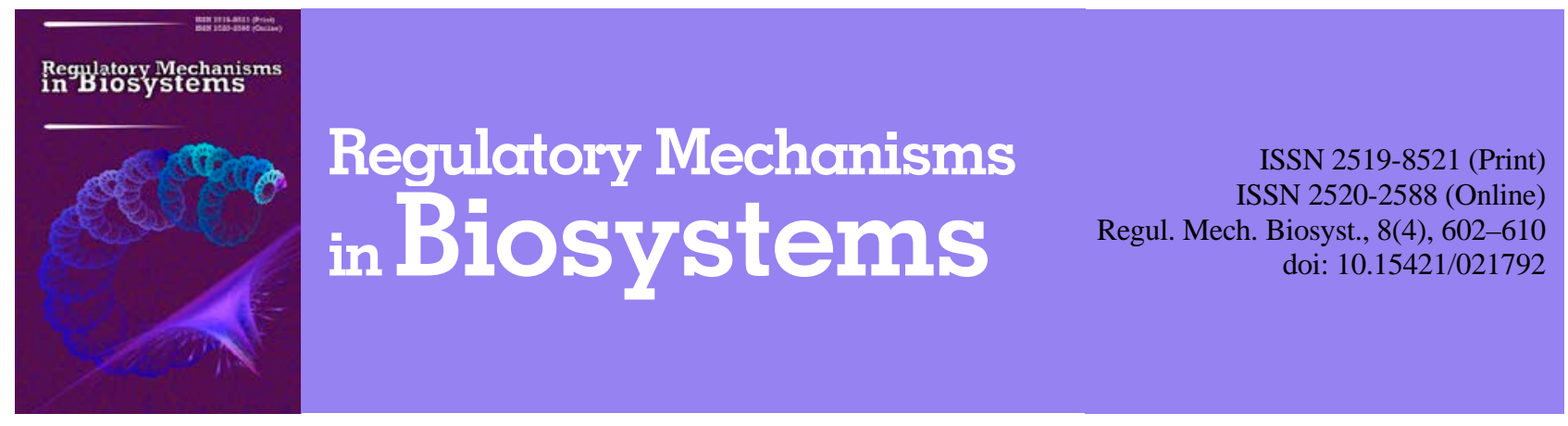

\title{
Epidemiology, etiology and gene analysis of spike S protein of porcine epidemic diarrhea virus infection in Ukraine during 2016-2017
}

\author{
D. M. Masiuk*, O. I. Sosnitsky*, V. S. Nedzvetsky*, **, A. V. Kokarev*, S. G. Koliada* \\ *Dnipro State Agrarian and Economic University, Dnipro, Ukraine \\ **Oles Honchar Dnipro National University, Dnipro, Ukraine \\ ***Bingol University, Bingol, Turkey
}

\section{Article info}

Received 15.09.2017

Received in revised form 28.10.2017

Accepted 02.11.2017

Dnipro State Agrarian and

Economic University,

Sergei Efremov Str., 25,

Dnipro, 49600, Ukraine

Tel.+38-056-236-17-14.

E-mail:plppm@ua.fm

Oles Honchar Dnipro

National University,

Gagarin Ave., 72, Dnipro,

49010, Ukraine.

E-mail:

nedzvetskyvictor@gmail.com

Bingol University,

Selahaddin-i Eyyubi Mah.

Aydinlik Cad., 12000,

Bingol, Turkey.

\begin{abstract}
Masiuk, D. M., Sosnitsky, O. I., Nedzvetsky, V. S., Kokarev, A. V., \& Koliada, S. G. (2017). Epidemiology, etiology and gene analysis of spike $S$ protein of porcine epidemic diarrhea virus infection in Ukraine during 2016-2017. Regulatory Mechanisms in Biosystems, 8(4), 602-610. doi:10.15421/021792
\end{abstract}

The spread of PEDV of pigs continues in various countries and regions of the world. PED was first registered in several areas of Ukraine in 2014. At present, there is a limited number of publications on the characteristics of the spread of the virus infection in Ukraine. Moreover, obtained research data do not clarify the epizootic situation as a whole. Having regard to the state of pig farm industry and permanent growth of losses caused with PEDV infection, the study of PED in Ukraine is relevant and important. Therefore, the goal of the work was to clarify the epizootic situation of PED in various areas of Ukraine. We studied the epizootic state of PED with a typical course in pig farms and the made a primary assessment of the relation of genetic groups between identified pathogens from distinct regions of the country where the highest intensity of the epizootic process was determined. The work was carried out in the Biosafety Center (Ukraine). To determine the epizootic situation of PED during 2016-2017 we collected samples of the blood serum and biological materials from pigs from 105 agricultural enterprises that are located in 85 administrative regions of Ukraine. In total we tested 543 serum samples and 591 samples of pathological tissues. The detection of PEDV was performed by PCR-RT. Serological diagnostics were tested with ELISA. Sequence analysis was performed according to Sanger. The results of sequences were analyzed in the FinchTV / Chromas program. The analysis of the epizootic features of PED in different areas of Ukraine for2016-2017 established that PEDV is the main causative agent of the infection. An infection circulates among sensitive animals in pig farms and induces PED, which is difficult to control and weakly managed as a particularly dangerous emergent infectious disease of pigs. In 2016, 6.5\% of administrative districts located in 12 of the 25 regions of Ukraine were included in the study, and in 2017, $10.8 \%$ of administrative districts located in the 14 regions of the 25 regions of the country were investigated. In general, during 2016 and 20171134 samples of blood serum and animal tissue were collected from 105 agricultural enterprises from $17.3 \%$ of the administrative regions of Ukraine. The obtained results showed that in 2016 PED was registered in 7 administrative districts from 4 regions of Ukraine, and in 2017 the infection was registered in 2 regions. The results of RNA sequence analysis of the PED virus identified the characteristics of the PEDV genes which reflect a high degree of homology with the Chinese strain BJ-2011-1. The analysis of the obtained results revealled the relation of PEDV circulating in Ukraine to the strains identified in the USA. Moreover, the samples of PEDV from Ukrainian pig farms have the sequences that belong to the North American clade II from the group of 2 strains of the PED virus. However, the PEDV observed in Ukraine is different from them by at least one nucleotide replacement of the gene which codes a protein of the S domain. Based on the obtained results, it can be assumed that in Ukraine the PED virus could have spread from East Asia.

Key words: PEDV; Alphacoronavirus infection; epidemiology of PED in Ukraine; neonatal piglets; diarrhea syndrome

\section{Эпидемиология, этиология и геномный анализ белка $\mathrm{S}$ домена вируса эпидемической диареи свиней в Украине за 2016-2017 годы}

\author{
Д. Н. Масюк*, А. И. Сосницкий*, В. С. Недзвецкий**, ***, А. В. Кокарев*, С. Г. Коляда* \\ *Днепровский государственный аграрно-экономический университет, Днепр, Украина \\ **Днепровский национальный университет имени Олеся Гончара, Днепр, Украина \\ ***Бингельский университет, Бингель, Туричия
}

Выполнен анализ эпизоотической ситуации эпидемической диареи свиней (ЭДС) на территории Украины за 2016-2017 годы, который позволил установить, что возбудитель инфекции циркулирует среди чувствительных животных свиноводческих хозяйств и индуцирует ЭДС, которая является трудноконтролируемой и слабоуправляемой особо опасной эмерджентной заразной болезнью свиней. В 2016 году 
обследовано 6,5\% административных районов, территориально расположенных в 12 областях Украины, а за 2017 год исследовано $10,8 \%$ административных районов, расположенных на территории 14 из 25 областей страны. Методами ИФА и ПЦР исследовано 1134 пробы сывороток крови и биологического материала, отобранных от 105 сельскохозяйственных предприятий из 17,3\% административных районов Украины. За 2016 год ЭДС зарегистрирована на территории 7 областей (в Закарпатской, Львовской, Запорожской, Киевской, Винницкой, Днепропетровской и Черкасской), а в 2017-м инфекцию регистрировали в Запорожской и Днепропетровской областях. Результаты сиквенс-анализа РНК вируса ЭДС идентифицировали последовательность генома, которая имеет высокую степень гомологии с китайским штаммом ВJ-2011-1. Обнаруженные последовательности относятся к североамериканской кладе II из группы 2 штаммов вируса ЭДС и отличаются от них по меньшей мере одной нуклеотидной заменой гена, белка домена S. На основании полученных результатов можно предположить, что в Украине вирус ЭДС мог распространиться из Восточной Азии.

\section{Ключевые слова: PEDV; $\alpha$-коронавирусная инфекция; эпидемиология PEDV; неонатальные поросята; диарейный синдром}

\section{Введение}

Эпидемическая диарея свиней (ЭДС, PED) - особо опасная, эмерджентная, чрезвычайно контагиозная вирусная зоонозная болезнь свиней с фекально-оральным механизмом заражения и развитием летального диарейного синдрома у неимунных неонатальных поросят.

Возбудитель ЭДС - вирус эпидемической диареи свиней (Porcine epidemic diarrhea virus, PEDV), род Alphacoronavirus, подсемейство Coronavirinae, семейство Coronaviridae, отряд Nidovirales. Различают два типа вируса: первый вызывает диарею свиней на откорме и у взрослых особей, второй - только у поросят-сосунов. Вирус не создает перекрестный иммунитет с другими кишечными коронавирусами, поражает только домашних свиней (Chen et al., 2015). Основной источник инфекции - больные и переболевшие свиньи, выделение вируса происходит в основном с фекалиями, заражение осуществляется фекально-оральным путем в результате прямого или косвенного контакта (факторы передачи) с возбудителем (Song and Park, 2012; Lee et al., 2015; Jung and Saif, 2015).

Восприимчивы к ЭДС свиньи всех возрастов, однако наиболее чувствительны неонатальные поросята: до 5-дневного возраста (погибает до 100\% помета), к 10-му дню смертность уменьшается до 60\%, к 15 -му - до $30 \%$; далее не превышает 1 $3 \%$. У свиней на откорме инфекционный процесс протекает по факторному типу, преимущественно доброкачественно, без тяжелых патофизиологических изменений с последующим освобождением макроорганизма от возбудителя. Персистенция и носительство PEDV среди инфицированных животных на откорме не зарегистрированы (Alvarez et al., 2015; Annamalai et al., 2015).

Заболевание у неонатальных поросят протекает по классическому типу инфекционного процесса. Инфекция проявляется исключительно тяжелым острым патогенезом и высокой летальностью, сопровождается непрерывной изнуряющей водянистой диареей, дегидратацией, интоксикацией, метаболическим ацидозом, депрессией, упорной рвотой, истощением при нарастающей слабости, тонико-клоническими судорогами, предсмертным ступором с полной прострацией (Alvarez et al., 2015).

Новорожденные поросята на подсосе, заболевшие в первые дни жизни, гибнут через 2-4 дня в результате значительных патофизиологических повреждений в слизистой оболочке кишечника и метаболических нарушений гомеостаза, индуцированных PEDV в процессе репродукции в энтероцитах. В такой ситуации вакцинация крайне неэффективна и единственный способ специфической защиты от заражения для неонатальных поросят может быть реализован с помощью местного лактогенного иммунитета (Jung et al., 2015; Langel et al., 2016).

Несмотря на многочисленные исследования, специфические средства иммунопрофилактики ЭДС на сегодняшний день отсутствуют. Существующие коммерческие биопрепараты с аттенуированным или инактивированным возбудителем не обеспечивают надежной защиты от циркуляции возбудителя и не прерывают эпизотический процесс в условиях реального ведения отрасли. Низкая биологическая протективная активность существующих средств защиты привела к глобальной экспансии PEDV на поголовье свиней и не останавливает распространения PEDV инфекции (Sun et al., 2016). Сложность девитализации вируса в инфицированном организме и эрадикации в среде содержания животных приводит к формирова- нию стационарно неблагополучных очагов инфекции. Все эти факторы вместе обусловливают сложность противоинфекционных мероприятий и эмерджентность данного зооноза свиней (Stevenson et al., 2013; Stadler et al., 2015; Masiuk et al., 2017).

B неблагополучных очагах PEDV-инфекции происходят патогенетически критичные эволюционные процессы в межпопуляционных взаимоотношениях системы паразит - хозяин (Huang et al., 2013; Jarvis et al., 2016). Многоплодность свиней, быстрый рост потомства, интенсивная ротация поголовья в короткие сроки на ограниченной территории обеспечивают значительную вариабельность межпопуляционных отношений и индукцию биоразнообразия генетического потенциала вируса. Широкая вариабельность физиологических особенностей особей в хозяйстве вместе с иммуносупрессивным эффектом инфекции способствуют высокой частоте мутаций и генерации разнообразия вирусного генотипа (Bi et al., 2012; Marthaler et al., 2014; Grasland et al., 2015).

Клинико-эпизоотологические генетические модификации PEDV-популяций определяют изменения эпизоотических характеристик инфекционного процесса в разновозрастных группах поражаемых особей. Мутации PEDV ведут к увеличению вариабельности клинической симптоматики инфекционного процесса (Lin et al., 2017). В последние годы PEDV характеризуется расширением возрастного диапазона патогенного воздействия на более старшие возрастные группы с одновременным незначительным ослаблением тяжести патогенеза абдоминального синдрома, при этом неонатальные не иммунные поросята, по-прежнему остаются наиболее уязвимым звеном инфекционного генеза и подвержены массовой гибели (Stevenson et al., 2013; Dee et al., 2015).

В поддержании эпизоотологического процесса решающую роль играют механизмы резервации, поддержания и дальнейшей передачи инфекционного агента восприимчивым организмам для его воспроизводства и дальнейшего существования как определенного генотипа. Инфекционный процесс, индуцированный PEDV, реализуется у животных всех возрастных групп, но с широкой вариабельностью тяжести патогенеза, от классического типа инфекционного процесса на неимунных неонатальных поросятах с летальным диарейным синдромом до доброкачественного течения инфекции у физиологически половозрелых свиноматок с активно функционирующей иммунной системой (Goede and Morrison, 2015). В ходе инфекции персистенция PEDV, как правило, не выявляется у взрослых животных, которые, независимо от антиинфекционных мероприятий, освобождаются от возбудителя, что является важнейшей особенностью эпизоотического процесса PEDV в промышленных условиях. Во внешней среде свиноводческих комплексов биологических накопителей возбудителя также не обнаружено. Главным биоиндикатором циркуляции PEDV в экологической нише существования свиней являются неимунные неонатальные поросята, на которых возбудитель индуцирует классический тип инфекционного процесса с патогномонической картиной ЭДС: диарейный синдром с водянистым поносом и поголовной гибелью новорожденных поросят (Alvarez et al., 2015; Annamalai et al., 2015; Jung et al., 2015).

Наибольшую биологическую опасность представляет мутационный потенциал вирусной популяции PEDV при формировании эндемичных очагов инфекции, что приводит к постоянному рецидиву патогенеза и возобновлению симптомокомп- 
лекса диарейного синдрома с интервалом 4-12 месяцев в стабилизированных очагах инфекции (Song et al., 2015; Annamalai et al., 2015). Тяжесть эпизоотологической ситуации усугубляется отсутствием эффективных, кардинально блокирующих эпизоотический процесс беспрерывной передачи возбудителя от заболевших к здоровым, специфических биопрепаратов против различных вариантов генотипа PEDV. Одними из наиболее проблемных являются так называемые «полевые» эпизоотические варианты возбудителя с оригинальными молекулярно-генетическими характеристиками генофонда вирусной популяции. Совокупность неблагоприятных противоэпизоотических факторов приводит к возможности бесконтрольного распространения популяции PEDV на восприимчивых животных и создает бесконтрольную ситуацию неуправляемой эмерджентной инфекции как в отдельных хозяйствах, так и в пределах регионов (Kim et al., 2007; Wang et al., 2015).

Глобальное распространение PEDV-инфекции на поголовье свиней в различных странах и регионах мира сопровождается интенсивным ростом числа неблагополучных хозяйств и регионов. В литературе описаны особенности течения и проявления эпизоотии ЭДС, выделены и охарактеризованы биологические свойства эпизоотических вариантов возбудителя, исследованы генетические свойства вируса и описаны сиквенсы геномов, созданы коллекции референтных штаммов китайского и северо-американского происхождения (Fan et al., 2012; Huang et al., 2013; Fablet et al., 2014). Организационные усилия и информационные ресурсы МЭБ и национальных служб ветеринарной медицины не в состоянии остановить распространение ЭДС на восприимчивой популяции животных. Ветеринарно-карантинные и иммунобиологические мероприятия по локализации вируса ЭДС и контролю за его распространением в настоящее время являются недостаточно эффективными (Goede et al., 2016).

Впервые на территории Украины ЭДС зарегистрирована в 2014 году (Dastjerdi et al., 2015). На данный момент встречаются отдельные публикации (Choudhury et al., 2016, Chaika et al., 2016), авторы которых указывают на распространение вирусной инфекции на территории страны и не отображают эпизоотический ситуацию в полном объеме. Генетическое разнообразие эпизоотических вариантов возбудителя и его биологические свойства, которые обуславливают контагиозность, вирулентность и патогенность вируса, остаются неизученными.

Массовая гибель заболевших неонатальных поросят при отсутствии надежных и эффективных мероприятий специфической профилактики и терапии приводит к невозможности иммунобиологической коррекции эпизоотического процесса и делают ее трудноуправляемой. При этом в качестве средств борьбы используют в основном организационно-хозяйственные и карантинноветеринарные методы. Низкая эффективность методологии противоэпизоотических мероприятий дает основание считать ЭДС особо опасной и эмерджентной инфекционной патологией в свиноводстве (Wicht et al., 2014; Okda et al., 2015).

Цель этой статьи - выяснить эпидемиологию ЭДС на территории Украины за 2016-2017 годы с использованием методов ИФА и ПЦР, изучить эпизоотическую ситуацию $\alpha$-коронавирусной инфекции в свиноводческих хозяйствах с типическим течением ЭДС и провести первичную оценку генетической групповой принадлежности возбудителя инфекции, изолированного в регионе страны с наиболее высокой интенсивностью эпизоотического процесса.

\section{Материал и методы исследований}

Работа выполнена на базе Научно-исследовательского центра биобезопасности и экологического контроля ресурсов агропромышленного комплекса Днепровского государственного аграрно-экономического университета. Для проведения мониторинга с целью оценки распространения ЭДС на протяжении 2016-2017 годов отобраны образцы биологических субстратов (сыворотка крови, фекалии, фрагменты тонкого кишечника от павших животных) от свиней 105 сельскохозяйственных предприятий, расположенных в 85 административных районах Западного, Южного, Северного, Восточного и Центрального регионов Украины (табл. 1). Образцы отобраны от животных разных возрастных групп, у которых отмечали клинические проявления желудочно-кишечной патологии, сопровождающейся диарейным синдромом. Протестировано 543 образца сывороток крови и 591 образец биологического материала.

\section{Таблица 1}

Количество административных районов Украины, участвовавших в мониторинговых наблюдениях на протяжении 2016-2017 гг.

\begin{tabular}{|c|c|c|c|c|c|c|c|c|c|}
\hline \multirow{3}{*}{$\begin{array}{l}\text { Название } \\
\text { областей }\end{array}$} & \multirow{3}{*}{$\begin{array}{c}\text { Всего } \\
\text { райо- } \\
\text { нов }\end{array}$} & \multicolumn{4}{|c|}{2016} & \multicolumn{4}{|c|}{2017} \\
\hline & & \multicolumn{2}{|c|}{ ИФА } & \multicolumn{2}{|c|}{ ПЦР } & \multicolumn{2}{|c|}{ ИФА } & \multicolumn{2}{|c|}{ ПЦР } \\
\hline & & $\begin{array}{c}\text { райо- } \\
\text { нов }\end{array}$ & $\begin{array}{c}\text { хо- } \\
\text { зяйств }\end{array}$ & $\begin{array}{c}\text { райо- } \\
\text { нов }\end{array}$ & $\begin{array}{c}\text { хо- } \\
\text { зяйств }\end{array}$ & $\begin{array}{c}\text { райо- } \\
\text { нов }\end{array}$ & $\begin{array}{c}\text { хо- } \\
\text { зяйств }\end{array}$ & $\begin{array}{c}\text { райо- } \\
\text { нов }\end{array}$ & $\begin{array}{c}\text { хо- } \\
\text { зяйств }\end{array}$ \\
\hline \multicolumn{10}{|c|}{ Западный регион } \\
\hline Волынская & 16 & - & - & 1 & 1 & 2 & 2 & - & - \\
\hline Закарпатская & 13 & - & - & 1 & 1 & - & - & 2 & 2 \\
\hline $\begin{array}{l}\text { Ивано- } \\
\text { Франковская }\end{array}$ & 14 & - & - & - & - & 2 & 2 & 1 & 2 \\
\hline Львовская & 20 & - & - & 1 & 1 & 2 & 2 & - & - \\
\hline Ривненская & 16 & - & - & - & - & - & - & - & - \\
\hline Тернопольская & 17 & - & - & - & - & - & - & - & - \\
\hline Хмельницкая & 20 & - & - & - & - & 2 & 2 & 1 & 2 \\
\hline Черновицкая & 11 & - & - & - & - & - & - & - & - \\
\hline \multicolumn{10}{|c|}{ Южный регион } \\
\hline АР Крым & 14 & - & - & - & - & - & - & - & - \\
\hline Запорожская & 20 & 3 & 3 & 3 & 3 & 4 & 4 & 3 & 4 \\
\hline Николаевская & 19 & 2 & 2 & - & - & - & - & - & - \\
\hline Одесская & 26 & - & - & - & - & 2 & 2 & 2 & 2 \\
\hline Херсонская & 18 & - & - & 1 & 1 & - & - & - & - \\
\hline \multicolumn{10}{|c|}{ Северный регион } \\
\hline Житомирская & 23 & - & - & - & - & - & - & - & - \\
\hline Киевская & 25 & - & - & - & - & - & - & 2 & 2 \\
\hline Сумская & 18 & - & - & - & - & 2 & 2 & 1 & 2 \\
\hline Черниговская & 22 & 1 & 1 & 1 & 1 & - & - & - & - \\
\hline \multicolumn{10}{|c|}{ Восточный регион } \\
\hline Донецкая & 18 & - & - & - & - & - & - & - & - \\
\hline Луганская & 18 & - & - & - & - & - & - & - & - \\
\hline Харьковская & 27 & - & - & - & - & 2 & 2 & 2 & 4 \\
\hline \multicolumn{10}{|c|}{ Центральный регион } \\
\hline Винницкая & 27 & - & - & 1 & 1 & - & - & - & - \\
\hline Днепропетровская & 22 & 5 & 5 & 5 & 6 & 4 & 4 & 4 & 10 \\
\hline Кировоградская & 21 & 2 & 2 & 2 & 2 & 2 & 2 & 5 & 8 \\
\hline Полтавская & 25 & - & - & 2 & 2 & 2 & 2 & 1 & 2 \\
\hline Черкасская & 20 & - & - & 1 & 2 & 2 & 2 & 1 & 4 \\
\hline
\end{tabular}

Примечание: «-»- не исследовано.

В 2016 году в Западном регионе с помощью ИФА и ПЦР исследован биологический материал от свиней трех свиноводческих комплексов из трех областей. За 2017 год исследовано 14 свиноводческих предприятий из 12 административных районов пяти областей Западного региона.

Результаты мониторинговых исследований Южного региона методами ИФА и ПЦР охватывают четыре из пяти имеющихся областей. В 2016 году исследован материал 9 свиноводческих предприятий, расположенных в 9 административных районах трех из пяти областей. За 2017 год исследовано 12 предприятий из 11 административных районов двух из пяти областей Южного региона Украины.

За 2016 год в Северном регионе с помощью иммунохимических и молекулярно-генетических методов лабораторной диагностики исследован биологический материал от свиней двух свиноводческих ферм, расположенных в двух районах Черниговской области. В 2017 году исследованы пробы из шести сельскохозяйственных предприятий из пяти различных административных районов Украины, которые входят в состав двух областей Северного региона.

Клинико-эпизоотологический мониторинг Восточного региона Украины в 2016 году не проводился. В 2017 году проведены 
ИФА и ПЦР исследования биологического материала и сывороток крови свиней шести свиноводческих фирм, расположенных в четырех административных районах Харьковской области.

Результаты мониторинговых исследований Центрального региона методами ИФА и ПЦР охватывают все пять областей. Анализировали биологический материал и сыворотки крови от свиней 20 сельскохозяйственных предприятий из 18 административных районов, распределенных во всех областях региона. В 2017 году исследовано 34 предприятия из 21 административного района в четырех из пяти областей Центрального региона Украины. Таким образом, в Центральном регионе Украины за 2016 год обследовано 15,7\% административных районов, а за 2017 - 18,3\% районов, располагающихся в четырех из пяти областей центральных территорий Украины.

Таким образом, клинико-эпизоотологическим мониторингом ЭДС в 2016 году охвачено 6,5\% административных районов 12 из 25 областей Украины, в $2017-10,8 \%$ районов в 14 областях страны.

Исследования проводили с помощью серологических (ИФА) и молекулярно-генетических (ПЦР, секвенирование) методов лабораторной диагностики ЭДС.

Выявление и дифференциацию вируса ЭДС в биологическом материале осуществляли методом ПЦР с помощью тестсистемы EZ-RED/TGE/PDCoV MPX 1.0 Realtime RT-PCR фирмы Tetracore (США). Амплификации и детекцию результатов проводили на приборе CFX 96 Real-TimeSystemfirms фирмы BioRad (США) с программным обеспечением к нему BioRad CFX Manager.

Серологическую диагностику ЭДС проводили с помощью ИФА, используя тест-системы Swinecheck ${ }^{\circledR}$ PED фирмы Biove (Канада) и ID Screen ${ }^{\circledR}$ PEDV Indirect фирмы IDVet (Франция) на иммуноферментном анализаторе-фотометре BioTek ELx800 (США). Согласно инструкции к набору Swinecheck ${ }^{\circledR}$ PED, сыворотки считали положительными по ЭДС при значении расчетного показателя S/P в образце выше 0,4 ед., в разведении $1: 200$, а при использовании набора ID Screen ${ }^{\circledR}$ PEDV Indirect сыворотки считали положительными по ЭДС при значении расчетного показателя S/P в образце выше $60 \%$, в разведении $1: 10$.

Для секвенирования положительные пробы, выявленные в ходе исследования наличия вируса ЭДС в образцах кишечника и фекалий, которые получены от больных животных, клонированы в вектор pGEM-T (производства фирмы Promega, США) методом ТА-клонирования. Плазмиды, содержащие вставку, отбирали методом бело-голубой селекции на твердой среде с агаром, содержащим IPTG (изопропил $\beta$-D-1-тиогалактопиранозид). Положительные клоны высевали в ночную культуру на жидкой среде, содержащую селективный антибиотик (ампициллин), из которой на следующий день выделяли плазмидную ДНК методом щелочного лизиса (Lee and Rasheed, 1990). Далее проводили двунаправленное секвенирование по Сэнгеру выделенных плазмид из праймеров, фланкирующих вставку (М13forward: 5'-GTAAAACGACGGCCAGT-3' и M13 reverse: 5'AACAGCTATGACCATG-3') на автоматическом секвенатоpe 3500 GeneticAnalyzer (Applied Biosystems, FosterCity, CA) c использованием набора BigDye ${ }^{\circledR}$ Terminator v1.1 CycleSequencingKit (Applied Biosystems).

Полученные секвенограммы анализировали в программе FinchTV/Chromas. Индивидуальные последовательности, выявленные в ходе исследования, сравнивали с типовыми и хорошо охарактеризованными штаммами вируса эпидемической диареи свиней для множественного выравнивания, построения филогенетического древа и определения групповой принадлежности, идентификационные номера которых в базе данных GenBank приведены ниже: Z25483, AB548623, AB548624, AB548618, AB548622, AY167585, GU180142, GU180143, GU180144, GU180145, GU180146, GU180147, AY653204, EU031893, DQ985739, AJ271965, AF304460, AF353511, GU937797, JQ023162, JQ023161, EF185992, JN547228, JQ282909, JN825712, JX261936, KR265804, KJ503833,
KJ645688, KU133249, KU133240, KJ645696, KJ645695, KJ645700, KF468752. Последовательности выбраны из литературных источников (Pan et al., 2012; Vlasova et al., 2013).

\section{Результаты}

За 2016 год из Западного региона методом ПЦР протестировано 9 образцов биологического материала из трех областей, в результате чего генетический материал вируса ЭДС выявлен в $25,1 \%$ образцов Закарпатской и $100 \%$ образцов Львовской области (табл. 2). В биологическом материале из Волынской области РНК вируса ЭДС не обнаружено. Исследования 2017 года представлены результатами серологического анализа 135 сывороток крови и ПЦР тестирования 34 проб биологического материала из пяти областей региона, в результате чего иммуноглобулины к антигенам вируса ЭДС и РНК вируса не обнаружены.

\section{Таблица 2}

Результаты лабораторных исследований по обнаружению в биологическом материале РНК возбудителя ЭДС (ПЦР-исследования) и специфических антител (ИФА-исследования) к его антигенам на территории Украины за 2016-2017 гг.

\begin{tabular}{|c|c|c|c|c|c|c|c|c|}
\hline \multirow{4}{*}{ Название областей } & \multicolumn{4}{|c|}{2016} & \multicolumn{4}{|c|}{2017} \\
\hline & \multicolumn{2}{|c|}{ ИФА } & \multicolumn{2}{|c|}{ ПЦР } & \multicolumn{2}{|c|}{ ИФА } & \multicolumn{2}{|c|}{ ПЦР } \\
\hline & \multicolumn{2}{|c|}{$\begin{array}{l}\text { иссле- поло- } \\
\text { дован- жител }\end{array}$} & \multicolumn{2}{|c|}{$\begin{array}{l}\text { иссле- поло- } \\
\text { дован- житель }\end{array}$} & \multicolumn{4}{|c|}{$\begin{array}{l}\text { иссле- поло- иссле- поло- } \\
\text { дован- житель дован- житель }\end{array}$} \\
\hline & ных & ных & ных & Hых & ных & ных & ных & ных \\
\hline \multicolumn{9}{|c|}{ Западный регион } \\
\hline Волынская & - & - & 2 & 0 & 65 & 0 & - & - \\
\hline Закарпатская & - & - & 4 & 1 & - & - & 18 & 0 \\
\hline Ивано-Франковская & - & - & - & - & 30 & 0 & 10 & 0 \\
\hline Львовская & - & - & 3 & 3 & 20 & 0 & - & - \\
\hline Ривненская & - & - & - & - & - & - & - & - \\
\hline Тернопольская & - & - & - & - & - & - & - & - \\
\hline Хмельницкая & - & - & - & - & 20 & 0 & 6 & 0 \\
\hline Черновицкая & - & - & - & - & - & - & - & - \\
\hline \multicolumn{9}{|c|}{ Южный регион } \\
\hline АР Крым & - & - & - & - & - & - & - & - \\
\hline Запорожская & 56 & 8 & 121 & 92 & 38 & 0 & 37 & 6 \\
\hline Николаевская & - & - & - & - & - & - & - & - \\
\hline Одесская & 30 & 2 & 2 & 0 & 15 & 0 & - & - \\
\hline Херсонская & - & - & - & - & - & - & - & - \\
\hline \multicolumn{9}{|c|}{ Северный регион } \\
\hline Житомирская & - & - & - & - & - & - & - & - \\
\hline Киевская & - & - & 2 & 2 & - & - & 4 & 0 \\
\hline Сумская & - & - & - & - & 36 & 0 & 10 & 0 \\
\hline Черниговская & 15 & 0 & 4 & 0 & - & - & - & - \\
\hline \multicolumn{9}{|c|}{ Восточный регион } \\
\hline Донецкая & - & - & - & - & - & - & - & - \\
\hline Луганская & - & - & - & - & - & - & - & - \\
\hline Харьковская & - & - & - & - & 60 & 0 & 46 & 0 \\
\hline \multicolumn{9}{|c|}{ Центральный регион } \\
\hline Винницкая & - & - & 7 & 6 & - & - & - & - \\
\hline Днепропетровская & 33 & 8 & 24 & 18 & 34 & 5 & 34 & 0 \\
\hline Кировоградская & 4 & 0 & 30 & 0 & 26 & 0 & 41 & 0 \\
\hline Полтавская & - & - & 6 & 0 & 26 & 0 & 7 & 0 \\
\hline Черкасская & - & - & 165 & 104 & 35 & 0 & 8 & 0 \\
\hline
\end{tabular}

Примечание: “-”- - не исследовано.

Анализ результатов диагностики ЭДС в разных районах Юга Украины показал, что в 2016 г. из 86 проб сывороток специфические иммуноглобулины к антигенам вируса выявлены в $14,3 \%$ образцах из Запорожской и в 7,2\% из Одесской области. Также из 123 образцов биоматериала РНК вируса обнаружено в 76,0\% образцов привезенных из Запорожской области. Все пробы, тестируемые из Одесской области вируснегативны. В 2017 году методом ИФА протестировано 53 пробы сыворотки крови, которые показали отрицательный результат, а также 37 проб биоматериала, которые во время генетического анализа идентифицировали геном вируса ЭДС в 16,2\% проб из Запорожской области. За 2016 год антитела к вирусу ЭДС обнаружены в 12,4\% образцов сывороток крови из Запо- 
рожской и Одесской областей, а РНК вируса идентифицирована в 76,1\% образцов только из Запорожской области. За 2017 год иммуноглобулины к возбудителю ЭДС не обнаружены ни в одной из областей Южного региона, а генетический материал вируса выявлен в 16,3\% образцов Запорожской области.

Результаты диагностики ЭДС показывают, что в 2016 году серологически инфекция не обнаружена, тогда как при исследовании биоматериала $100 \%$ образцов из Киевской области содержали геном вируса ЭДС. ИФА и ПЦР исследования, проведенные в 2017 году, показывают 100\% отрицательный результат.

Анализ результатов диагностики ЭДС в Восточном регионе показал, что в 2017 г. из свиноводческих предприятий отобрано и протестировано 60 образцов сывороток крови и 46 образцов биологического материала. Полученные результаты являются 100\% отрицательными. В 2016 г. аналогичные исследования не проводились.

Результаты диагностики ЭДС в Центральном регионе Украины показывают, что в 2016 г. из 37 исследованных проб специфические иммуноглобулины к антигенам вируса выявили в $24,0 \%$ образцов сывороток крови из Днепропетровской области. Исследование 232 образцов биологического материала методом ПЦР за этот период вывило присутствие РНК вируса ЭДС в $86,3 \%$ образцов Винницкой области, 75,1\% образцов Днепропетровской области и $63,3 \%$ образцов из Черкасской области. В 2017 г. из 121 образца сыворотки крови, тестированного методом ИФА, обнаружены специфические антитела к антигенам вируса в $15,2 \%$ проб из Днепропетровской области. Также за этот период методом ПЦР протестировано 90 образцов биологического материала, из которых ни в одном случае не обнаружено генетического материала вируса ЭДС.

На сновании официальных данных в Центральном регионе Украины в 2016 году ЭДС выявлен в Винницкой, Днепропетровской и Черкасской областях, а в 2017-м - только в Днепропетровской.

Суммируя результаты мониторинговых исследований ЭДС в Украине за 2016 год, следует отметить, что всего протестировано методом ИФА 138 образцов сывороток крови и методом ПЦР - 370 образцов биологического материала, из которых в 13,3\% образцов сывороток обнаружены специфические иммуноглобулины к антигенам вируса ЭДС и в $61,1 \%$ образцов биологического материала выявлено генетический материал эпизоотического штамма вируса. На протяжении 2017 года методом ИФА исследовано 405 образцов сывороток крови, из которых $1,2 \%$ содержали специфические антитела к вирусу ЭДС. Методом ПЦР протестирован 221 образец биологического материала. При этом РНК вируса ЭДС идентифицирован в 2,5\% проб.

На сновании официальных данных, всего за период с 2016 по 2017 гг. методами ИФА и ПЦР исследованы 1134 пробы сывороток крови и биологического материала, отобранные в 105 сельскохозяйственных предприятиях из 17,3\% административных районов Украины. Специфические антитела к вирусу ЭДС или его РНК обнаружены у $23,2 \%$ исследованных образцов, из которых 52,0\% принадлежат предприятиям Центрального региона Украины.

Таким образом, за 2016 год ЭДС зарегистрирована на территории семи областей из четырех регионов Украины: в Закарпатской, Львовской, Запорожской, Киевской, Винницкой, Днепропетровской и Черкасской, а за 2017 год инфекцию регистрировали в Запорожской и Днепропетровской областях.

Особое внимание в наших исследованиях уделено именно эпизоотологическим аспектам распространения ЭДС и сопровождающей ее симптоматике у инфицированных животных с анализом анамнестических клинико-эпизоотологических данных ретроспективного обзора инфекционной ситуации с патогномоническим симптомом «водянистая диарея» у неонатальных поросят. При этом в процессе обработки значительного массива клинической информации выведены общие типичные закономерно повторяющиеся особенности в формировании эпи- зоотического очага, от его возникновения, при проникновении инфекционного агента до его ликвидации, при полной эрадикации возбудителя из экологической ниши обитания чувствительных животных и технологическом оборудовании.

После появления $\alpha$-коронавирусной инфекции в ранее благополучном хозяйстве, вследствие недостаточного уровня биобезопасности хозяйства и неудовлетворительного соблюдения основополагающих ветеринарно-санитарных требований по недопущению проникновения инфекции и выполнения правила «все занято - все пусто» возникала первоначальная вспышка ЭДС в виде легкого течения водянистой диареи возникла среди инфицированных животных, чаще всего ремонтных свиноматок.

Массовая вспышка ЭДС возникает через 24-48 часов после появления инфекции на территории предприятия. Кишечная патология в течение 3-5 суток распространилась на большую часть свиноматок свинарника, у четверти стада расстройства дефекации не регистрируются. Симптомокомплекс кишечного расстройства включал скоротечную водянистую диарею без выраженных тяжелых патофизиологических и общеорганизменных отклонений от физиологической нормы, температурная реакция отсутствовала, поедаемость корма уменьшилась, поведенческие реакции характеризовались незначительным угнетением. Через 5-6 суток после появления первых случаев относительно легкого клинического течения диареи состояние животных в свинарнике приходило в норму.

Впоследствии клинически энзоотия ЭДС появлялась у неонатальных поросят. Поросята начинали поносить через сутки после рождения, у большей части животных понос начинался на вторые - третьи сутки, реже диарея появлялась на четвертые - шестые сутки. Диарея сочеталась с рвотой. Фекалии сразу разжижались и превращались в водянистые испражнения, бесцветные или зеленовато-желтые, без примеси крови. Диарея не проходила круглосуточно и быстро приводила к дегидратации, животные худели, у них начинали контурировать ребра, позвоночник, маклоки. Кожа становилась морщинистой, неэластичной, сухой, шероховатой. Угнетение физиологических функций организма поросят быстро усиливалось, животные заметно слабели на фоне токсических явлений в сочетании с метаболическим ацидозом. Через три - шесть суток течения диарейного синдрома, на фоне гипотермии и прогрессирующего истощения, поросята погибали. Летальность среди поросят, у которых клинические проявления возникали в первые 72 часа жизни, составила $100 \%$. Во время вскрытия характерные признаки представлены комплексом патологических изменений, состоящим из дегидратации, истощения, анемии, тяжелейшей интоксикации в сочетании с явлениями метаболического ацидоза и алиментарной астении. В ЖКТ ярко выражены признаки катарально-геморрагического энтероколита и десквамации секреторного эпителия тонкого и толстого кишечника. Печень, почки и сердечная мышца в состоянии дистрофии (белково-липидной). Регионарные лимфоузлы отечны и гиперемированны. Селезенка не увеличена, ярко-красного цвета. Слизистые и кожа анемичны, кровь в сосудах не свернулась, жировые депо внутренних органов истощены.

Незначительная часть животных, около $20 \%$ от заболевших, у которых признаки диареи проявились на четвертые пятые сутки, после тяжелого переболевания, длившегося более 10 суток, на фоне рутинной терапии неспецифического характера выжили, но они уже не представляли хозяйственной ценности, отнесены к санитарному браку и удалены из стада.

Диагноз на ЭДС устанавливали с помощью комплексных клинико-эпизоотологических и лабораторных исследований с применением методов ИФА и ПЦР для тестирования сыворотки крови и проб фекалий от заболевших поросят.

Поросята, заболевшие после двухнедельного возраста, переносили энтеральные расстройства значительно легче, с незначительным отходом, не имеющим существенного эпизоотического значения, выздоравливали. После переболевания на- 
блюдалась двухнедельная задержка физиологического развития - постинфекционная астения, с последующим, практически полным восстановлением откормочных кондиций. Для месячных и более старших животных возбудитель ЭДС уже не представлял эмерджентной угрозы.

Персистенция вируса в реконвалесцентном организме не зафиксирована, технологические объекты могут быть только механическим фактором передачи возбудителя инфекции в течение времени сохранения жизнеспособности вируса ЭДС. Стабилизация эпизоотического очага инфекции опосредуется за счет сохранения вируса во внешней среде, в результате некачественной дезинфекции и при формировании не иммунного молодняка от ремонтных свиноматок, у которых вследствие ювенальной физиологической недостаточности функциональной активности иммунной системы синтезируются специфические протективные иммуноглобулины в низких титрах, что ведет к формированию слабопротективного лактогенного мукозного иммунитета у неонатальных поросят и его последующему прорыву высоковирулентным эпизоотическим вариантом вируса ЭДС.

Для первичной оценки биологических свойств и генетической характеристики эпизоотического варианта вируса ЭДС, выделенного из биологического материала, отобранного от свиней с типичным течением заболевания, от одного из свиноводческих комплексов Центрального региона Украины проведено определение его генетического происхождения и сравнение генетических характеристик с референтными образцами генофонда американских и китайских образцов возбудителя ЭДС.

Выяснение филогенеза образцов PEDV выполнено с помощью сиквенс-анализа фрагмента геномной РНК ЭДС, изолированного из биологического материала неонатальных свиней с проявлениями диарейного синдрома. Полученные результаты секвенированных вставок генетического материала вируса ЭДС имели следующие последовательности (приведены в формате fasta):

1. CAAATMAWAGGCTACTAACGGTAACACTAATGCTAC TGCGCGATTGCGCATTTGCCAGTTTCCTAGCATTAAAAC ATTGGGCCCCACTGCTAATAATGATGTTACAACAGGTCG TAATTGCCTATTTAACAAAGCCATCCCAGCTCATATGAG
TGAACATAGTGTTGTCGGCATAACATGGGATAATGATCG TGTCACTGTCTTTTCTGACAAGATCTATTATTTTTATTTT AAAAATGATTGGTCCCGTGTTGCGACAAAGTGTTACAAC AGTGGAGGTTGTGCTATGCAATATGTTTACGAACCCACC TATTACATGCTTAATGTTACTAGTGCTGGTGAGGATGGT ATTTCTTATCAACCCTGTACAGCTAATTGCATTGGTTATG CTGCCAATGTATTTGCTACTGAGCCCAATGGCCACATAC CAGAAGGTTTTAGTTTTAATAATTGGTTTCTTTTGTCCAA TGATTCCACTTTGGTGCATGGTAAGGTGGTTTCTAACCA ACCATTGTTGGTCAATTGTCTTTTGGCCATTCCTAAGATT TATGGACTAGGCCAATTTTTCTCCTTTAATCAAACGATC GATGGTGTTTGTAATGGAGCTGCTGTGCAGCGTGCACCA GAGGCTCTGAGGTTTAATATTAATGACACCTCTGTCATT CTTGCTGAAGGCTCAATAAAAA

2. CTTTTTMMTAAGGCTACTAACGGTAACACTAATGCTA CTGCGCGATTGCGCATTTGCCAGTTTCCTAGCATTAAAA CATTGGGCCCCACTGCTAATAATGATGTTACAACAGGTC GTAATTGCCTATTTAACAAAGCCATCCCAGCTCATATGA GTGAACATAGTGTTGTCGGCATAACATGGGATAATGATC GTGTCACTGTCTTTTCTGACAAGATCTATTATTTTTATTT TAAAAATGATTGGTCCCGTGTTGCGACAAAGTGTTACAA CAGTGGAGGTTGTGCTATGCAATATGTTTACGAACCCAC CTATTACATGCTTAATGTTACTAGTGCTGGTGAGGATGG TATTTCTTATCAACCCTGTACAGCTAATTGCATTGGTTAT GCTGCCAATGTATTTGCTACTGAGCCCAATGGCCACATA CCAGAAGGTTTTAGTTTTAATAATTGGTTTCTTTTGTCCA ATGATTCCACTTTGGTGCATGGTAAGGTGGTTTCTAACC AACCATTGTTGGTCAATTGTCTTTTGGCCATTCCTAAGAT TTATGGACTAGGCCAATTTTTCTCCTTTAATCAAACGAT CGATGGTGTTTGTAATGGAGCTGCTGTGCAGCGTGCACC AGAGGCTCTGAGGTTTAATATTAATGACACCTCTGTCAT TCTTGCTGAAGGCTCAATAA

Анализ показал, что данные нуклеотидной последовательности являются характерными фрагментами гена, кодирующего белок $\mathrm{S}$ вируса (структурный ген спайка).

Результаты определенной последовательности подвергнуты множественному нуклеотидному выравниванию с типовыми последовательностями штаммов вируса ЭДС, на основании которого построено филогенетическое древо (рис.).

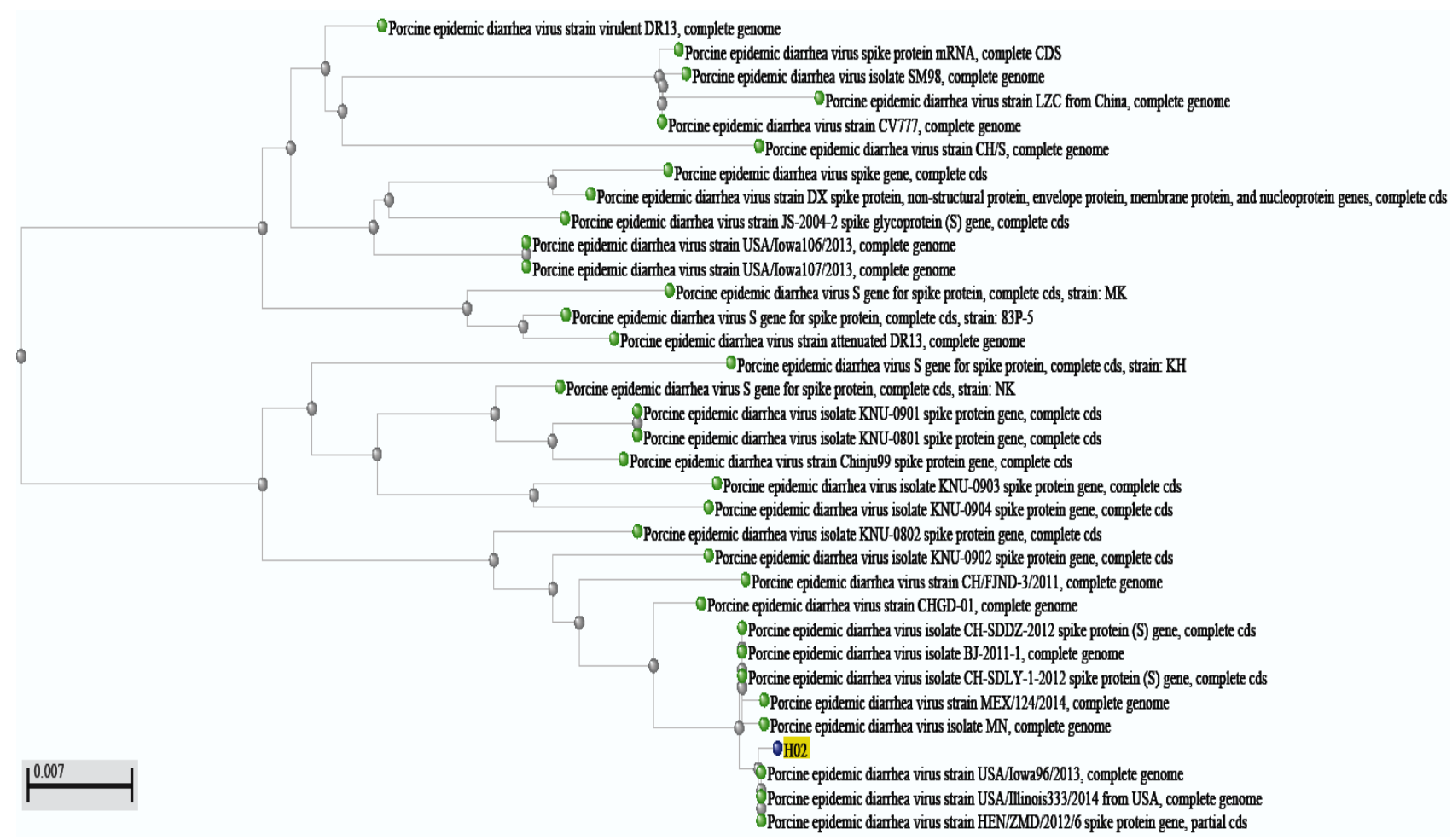

Рис. Филогенетическое древо, построенное на основании результатов исследования последовательности фрагмента генома вируса ЭДС: определенные в ходе исследования последовательности выделены желтым цветом 
Результаты, представленные на кладограмме, указывают на то, что выявленный штамм наиболее близок к группе 2 (родственной китайскому штамму ВЈ-2011-1) североамериканской клади II вируса ЭДС. Обнаруженные последовательности относятся к североамериканской клади II из группы 2 штаммов вируса ЭДС и отличаются от них по меньшей мере одной нуклеотидной заменой гена, белка домена $\mathrm{S}$.

\section{Обсуждение}

Для свиноводческих хозяйств Украины ЭДС является новой инфекционной патологией, возбудитель которой обладает очень опасными для новорожденных поросят болезнетворными свойствами, главными из которых являются чрезвычайная заразность, высокая вирулентность и выраженный тропизм к эпителию тонкой кишки (Jung et al., 2015). При попадании в энтероциты кишечника возбудитель ЭДС активно репродуцируется, что приводит к гибели и десквамации эпителия и развитию всего последующего комплекса патогенетических изменений местного и общеорганизменного характера в виде диарейного синдрома и гибели поросят вследствие дегидратации, интоксикации, метаболического ацидоза и истощения (Jung and Saif, 2015; Alvarez et al., 2016; Chaika et al., 2016).

Основной симптомокомплекс ЭДС - «диарейный синдром» не является исключительной прерогативой этого заболевания, а встречается и при других инфекционных патологиях энтерального характера (Chen et al., 2015). Поэтому диагностика и мониторинг эпизоотической ситуации в свиноводческих хозяйствах Украины невозможна без эффективных инструментальных и объективных высокотехнологичных методов, таких как иммунохимический скрининг специфических иммуноглобулинов против антигенов возбудителя ЭДСв ИФА и индентификация РНК вируса в ПЦР (Kim et al., 2007). Также важны и информативны классические способы сбора и логической обработки клинико-эпизоотологических данных распространения и проявления ЭДС в неблагополучном пункте на чувствительных животных (Okda et al., 2015; Jung and Saif, 2015; Song and Park, 2015).

Результаты лабораторных исследований сывороток крови от больных животных методом ИФА и фекалий методом ПЦР позволили установить неблагополучную ситуацию в распространении ЭДС на большей части территории Украины в 2016-2017 годах, кроме Восточного региона, включающего Донецкую, Луганскую и Харьковскую области. Наибольшее количество положительных результатов лабораторной диагностики выявлено в образцах из Южного и Центрального регионов Украины, где в среднем этот показатель составляет 36,1\% и 29,3\% диагностически положительных проб, соответственно, от общего количества поступивших на анализ. В Северном и Западном регионах Украины интенсивность эпизоотического процесса выражена значительно слабее, в долевом выражении это составило, соответственно, 3,2\% и 2,4\% диагностически положительных проб от общего количества поступивших на анализ. Количественно разница положительных результатов лабораторной диагностики ЭДС между территориальными формированиями с высоким и низким уровнем интенсивности эпизоотического процесса составляет один десятичный логарифм и является статистически достоверной.

Высокозначимым фактором, имеющим эпизоотологическое значение, является ветеринарно-санитарная культура ведения свиноводческой отрасли и уровень биобезопасности хозяйства (Song and Park, 2015; Jung and Saif, 2015; Masiuk et al., 2017). Традиционное ведение животноводства экстенсивного типа с неудовлетворительным уровнем противоинфекционной защиты приводит к тому, что в популяции чувствительных животных проникает возбудитель инфекции и, как следствие, вызывает эпизоотический процесс ЭДС. Занос возбудителя ЭДС возможен автотранспортом (особенно опасен автотранспорт мясокомбинатов), с животными, поступившими из неблагопо- лучного пункта, механическими переносчиками. Ретроспективно, на основании лабораторного анализа невозможно достоверно установить механизм и источники заноса инфекциионного агента, но факт возникновения ЭДС свидетельствует о нарушении ключевых ветеринарно-санитарных требований противоэпизоотической защиты животноводческого предприятия от заразных заболеваний (Dastjerdi et al., 2015; Choudhury et al., 2016). Возможно, что такие нарушения являются основной причиной того, что в 2016 году получено наибольшее количество положительных лабораторных диагностических результатов: в 13,3\% образцов обнаружены специфические иммуноглобулины к антигенам вируса ЭДС и в $61,1 \%$ образцов биологического материала выявлен генетический материал эпизоотического штамма вируса. В 2017 году наблюдали значительное снижение интенсивности эпизоотического процесса ЭДС на неблагополучных территориях Украины. Методом ИФА в 1,2\% образцов выявлены специфические антитела к антигену вируса ЭДС. Методом ПЦР РНК вируса ЭДС идентифицирована в 2,5\% проб. Этот положительный противоэпизоотический тренд объясняется активным проведением противоинфекционного санирования в неблагополучных хозяйствах, включающих весь комплекс ветеринарно-санитарных и противоэпизоотических мероприятий.

Основная проблема при разработке алгоритма противоэпизоотических мероприятий состоит в том, что заражение и заболевание неонатальных поросят происходит у тех особей, которые имеют повышенную чувствительность к вирусу ЭДС. В то же время, средства специфической профилактики, индуцирующие создание механизмов колострального мукозного иммунитета, являются недостаточно эффективными (Annamalai et al., 2015; Song et al., 2015; Langel et al., 2016). Своевременная индикация вируса ЭДС в окружающей среде затруднительна и часто бывает запоздалой, что ведет к вспышке летального энтерального расстройства у неимунных неонатальных поросят (Jung and Saif, 2015).

При низкой культуре животноводства и неудовлетворительном уровне биобезопасности на фоне нарушения базисных норм эпизоотологии наблюдается формирование стационарных очагов инфекции (Lee, 2015; Akimkin et al., 2016). Заболевание приобретает эндемический характер, что неизбежно сказывается на биологической системе «паразит - хозяин», так как свиньи являются скороспелыми многоплодными животными с частой сменой потомства, на которых и происходит экзальтированная ротация вирусных клонов (Song and Park, 2012; Masiuk et al., 2017). Это приводит к существенной вариабельности межпопуляционных взаимоотношений и индукции разнообразия генетического реагирования вирусного генома. Клинически генетические модификации вирусной популяции проявляются изменением эпизоотических особенностей течения инфекционной патологии на различных возрастных группах животных и небольшим ослаблением напряженности инфекционного процесса, смертность незначительно уменьшается, тяжесть патогенеза диарейного синдрома ослабевает, а временной диапазон поражения расширяется с неонатальных поросят на животных старших возрастных групп (Annamalai et al., 2015; Jung et al., 2015; Goede and Morrison, 2016).

PEDV характеризуется высоким тропизмом по отношению к энтероцитам свиней (Wicht et al., 2014). При вскрытии павших от «водянистой диареи» поросят патогномоническим признаком являются дегенеративные изменения в энтероцитах, прежде всего тощей кишки, с развитием атрофии и укорочением ворсинок и микроворсинок (Jung et al., 2015). Утрата микроворсинок приводит к уменьшению всасывающей функции поверхности тонкого кишечника, что в совокупности с функциональными нарушениями и слущиванием значительного количества энтероцитов приводит к пониженному всасыванию и основному симптому инфектопатологии - профузной диареи. Гибель поросят наступает от сочетанного воздействия интоксикации, ацидоза и дегидратации на фоне нарастающей про- 
страции и коматозного состояния (Annamalai et al., 2015; Goede and Morrison, 2016).

Методологическим базисом борьбы с вирусом ЭДС в технологической экосистеме обитания свиней является применение ветеринарно-карантинных и противоэпизоотологических методов воздействия, направленных на недопущение попадания возбудителя на свиноферму и эрадикацию вируса в окружающей технологической среде содержания свиней с помощью строжайшей дезинфекции до отрицательного результата в ПРЦ (Lee, 2015; Goede and Morrison, 2016). Для создания иммунного фона по отношению к возбудителю необходимо использовать иммунобиологические подходы, основанные на создании популяционной невосприимчивости чувствительной биосистемы к вирулентному возбудителю с помощью доступных иммунобиологических препаратов и приемов: вакцинации супороносных свиноматок в сочетании с «обратным скармливанием» инфицированным биоматериалом или одномоментным фекальным перезаражением половозрелых животных (Song et al., 2015; Langel et al., 2016). При этом необходимо удалить вирус из экосистемы обитания свиней и максимально повысить биобезопасность свиноводческого хозяйства (Song and Park, 2012; Jung and Saif, 2015).

Использование в качестве мер борьбы безвакциного варианта разрыва эпизоотической цепи, основанного на обратном скармливании инфицированного биоматериала от переболевших ЭДС поросят и эрадикации возбудителя из внешней среды обитания макроорганизма с помощью жесткой тотальной дезинфекции и жесткого соблюдения ветеринарно-санитарных правил ведения животноводства, приводит к тому, что вирус, покидая восприимчивый организм, погибает во внешней среде (Bowman et al., 2015; Goede and Morrison, 2016). Поэтому теоретически и практически возможна ликвидация эпизоотии ЭДС в отдельно взятом очаге инфекции при условии полной эрадикации возбудителя во внешней среде и создания надежного лактогенного иммунитета у неонатальных поросят (Choudhury et al., 2016; Dee et al., 2016).

Важнейшим направлением мониторинговых исследований эпизоотологии ЭДС является изучение молекулярно-генетических характеристик полевых изолятов вируса и коррелированных с генетическими особенностями штаммов биологическими свойствами, прежде всего вирулентностью и контагиозностью, а также иммуногенной способностью полевых изолятов и аттенуацией в различных биологических системах (Lin et al., 2017). Ограничения в использовании доступных для пролиферации PEDV клеточных культур в лабораторных условиях, а также референс-штаммов PEDV и, в частности, полевых изолятов возбудителя являются острой проблемой методологического характера, которая до сих пор не оптимизирована и не стандартизирована. Эти трудности являются одними из основных причин сложности пролиферации в культуре клеток биоматериала при процессе получения достаточного количества биоматериала PEDV при создании специфических профилактических биопрепаратов с аттенуированным или инактивированным возбудителем в составе вакцин и гипериммунных сывороток (Pan et al., 2012; Song and Park, 2012; Jarvis et al., 2016).

По результатам генетической характеристики эпизоотического изолята, а также кладограммы, определенной на основе данных сиквенс-анализа, установлено, что последовательности возбудителя соответствуют группе 2 (родственной китайскому штамму ВЈ2011-1) североамериканской клади II вируса ЭДС вместе с такими штаммами, как USA/Illinois/333/2014, USA/Iowa/2013 и др. От этих последовательностей выявленный штамм отличается одной нуклеотидной заменой (например, KJ645688.1:n.20965 C>T) (Marthaler et al., 2014; Jarvis et al., 2016).

\section{Выводы}

Анализ эпидемиологии ЭДС на территории Украины за 20162017 годы позволил установить, что возбудитель инфекции цир- кулирует среди чувствительных животных свиноводческих хозяйств и индуцирует ЭДС, которая является трудноконтролируемой и слабо управляемой особо опасной эмерджентной заразной болезнью свиней. В 2016 году обследовано 6,5\% административных районов, территориально расположенных в 12 из областей Украины, а за 2017 год исследовано 10,8\% административных районов, расположенных на территории 14 из 25 областей страны. За 2016-2017 годы методами ИФА и ПЦР исследовано 1134 пробы сывороток крови и биологического материала, отобранные от 105 сельскохозяйственных предприятий из 17,3\% районов Украины. За 2016 год ЭДС зарегистрирована на территории семи областей из четырех регионов Украины: Закарпатской, Львовской, Запорожской, Киевской, Винницкой, Днепропетровской и Черкасской, а за 2017 год инфекцию регистрировали в Запорожской и Днепропетровской областях.

Результаты сиквенс-анализа РНК вируса ЭДС идентифицировали последовательность генома, которая имеет высокую степень гомологии с китайским штаммом ВJ-2011-1. Обнаруженные последовательности относятся к североамериканской клади II из группы 2 штаммов вируса ЭДС и отличаются от них по меньшей мере одной нуклеотидной заменой гена, белка домена S. На основании полученных результатов можно предположить, что в Украине вирус ЭДС мог распространиться из Восточной Азии так же, как и из Северной Америки.

\section{References}

Akimkin, V., Beer, M., Blome, S., Hanke, D., Hoper, D., Jenckel, M., \& Pohlmann, A. (2016). New chimeric porcine coronavirus in swine feces, Germany, 2012. Journal Emerging Infectious Disease, 22, 1314-1315.

Alvarez, J., Sarradell, J., Morrison, R., \& Perez, A. (2015). Impact of porcine epidemic diarrhea on performance of growing pigs. Plos One, 10(3), e0120532.

Annamalai, T., Saif, L. J., Lu, Z., \& Jung, K. (2015). Age-dependent variation in innate immune responses to porcine epidemic diarrhea virus infection in suckling versus weaned pigs. Veterinary Immunology and Immunopathology. 168, 193-202

Bi, J., Zeng, S., Xiao, S., Chen, H., \& Fang, L. (2012). Complete genome sequence of porcine epidemic diarrhea virus strain AJ1102 isolated from a suckling piglet with acute diarrhea in China. Journal of Virology, 86, 10910-10911.

Bowman, A. S., Nolting, J. M., Nelson, S. W., Bliss, N., Stull, J. W., Wang, Q., \& Premanandan, C. (2015). Effects of disinfection on the molecular detection of porcine epidemic dianhea virus. Veterinary Microbiology, 179(3-4), 213-218.

Chaika, O. V., Holovko, V. O., Symonenko, S. I., \& Severyn, R. V. (2016). Epidemic swine diarrhea - new threat for pig farms in Ukraine. Scientific Messenger LNUVMBT named after S. Z. Gzhytskyj, 18(4), 134-138.

Chen, Q., Gauger, P., Stafne, M., Thomas, J., Arruda, P., Burrough, E., Madson, D., Brodie, J., Magstadt, D., Derscheid, R., Welch, M., \& Zhang, J. (2015). Pathogenicity and pathogenesis of a United States porcine deltacoronavirus cell culture isolate in 5-day-old neonatal piglets. Virology, 482, 51-59.

Choudhury, B., Dastjerdi, A., Doyle, N., Frossard, J. P., \& Steinbach, F. (2016). From the field to the lab - An European view on the global spread of PEDV. Journal of Virus Research, 226, 40-49.

Dastjerdi, A., Carr, J., Ellis, R. J., Steinbach, F., \& Williamson, S. (2015). Porcine epidemic diarrhea virus among farmed pigs, Ukraine. Emerging Infectious Diseases, 21(12), 2235-2237.

Dee, S., Neill, C., Singrey, A., Clement, T., Cochrane, R., Jones, C., Patterson, G., Spronk, G., Christopher-Hennings, J., \& Nelson, E. (2016). Modeling the transboundary risk of feed ingredients contaminated with porcine epidemic diarrhea virus. BMC Veterinary Research, 12(1), 12:51.

Fan, H., Zhang, J., Ye, Y., Tong, T., Xie, K., \& Liao, M. (2012). Complete genome sequence of a novel porcine epidemic diarrhea virus in South China. Journal of Virology, 86, 10248-10249.

Goede, D., \& Morrison, R. B. (2016). Production impact and time to stability in sow herds infected with porcine epidemic diarrhea virus (PEDV). Preventive Veterinary Medicine, 123, 202-207.

Grasland, B., Bigault, L., Bernard, C., Quenault, H., Toulouse, O., Fablet, C., Rose, N., Touzain, F., \& Blanchard, Y. (2015). Complete genome sequence of a porcine epidemic diarrhea $s$ gene indel strain isolated in france in december 2014. Genome Announcements, 3(3), e00535-15.

Huang, Y. W., Dickerman, A. W., Pineyro, P., Li, L., Fang, L., Kiehne, R., Opriessnig, T., \& Meng, X. J. (2013). Origin, evolution, and genotyping of emergent porcine epidemic diarrhea virus strains in the United States. mBio, 4(5), e00737-13. 
Jarvis, M. C., Lam, H. C., Zhang, Y., Wang, L., Hesse, R. A., Hause, B. M., Vlasova, A., Wang, Q., Zhang, J., Nelson, M. I., Murtaugh, M. P., \& Marthaler, D. (2016). Genomic and evolutionary inferences between American and global strains of porcine epidemic diarrhea virus. Preventive Veterinary Medicine, 123, 175-184.

Jung, K., \& Saif, L. J. (2015). Porcine epidemic diarrhea virus infection: Etiology, epidemiology, pathogenesis and immunoprophylaxis. Veterinary Journal, 204, 134-143.

Jung, K., Eyerly, B., Annamalai, T., Lu, Z., \& Saif, L. J. (2015). Structural alteration of tight and adherens junctions in villous and crypt epithelium of the small and large intestine of conventional nursing piglets infected with porcine epidemic diarrhea virus. Veterinary Microbiology, 177, 373-378.

Kim, S. H., Kim, I. J., Pyo, H. M., Tark, D. S., Song, J. Y., \& Hyun, B. H. (2007). Multiplex real-time RT-PCR for the simultaneous detection and quantification of transmissible gastroenteritis virus and porcine epidemic diarrhea virus. Journal of Virological Methods, 146, 172-177.

Langel, S. N., Paim, F. C., Lager, K. M., Vlasova, A. N., \& Saif, L. J. (2016). Lactogenic immunity and vaccines for porcine epidemic diarrhea virus (PEDV): Historical and current concepts. Virus Research, 226, 93-107.

Lee, C. (2015). Porcine epidemic diarrhea virus: An emerging and re-emerging epizootic swine virus. Virology Journal, 12, 193.

Lee, S. Y., \& Rasheed, S. A. (1990). Simple procedure for maximum yield of high-quality plasmid DNA. Biotechniques, 9(6), 676-679.

Lin, C. M., Annamalai, T., Liu, X., Gao, X., Lu, Z., El-Tholoth, M., Hu, H., Saif, L. J., \& Wang, Q. (2015). Experimental infection of a US spike-insertion deletion porcine epidemic diarrhea virus in conventional nursing piglets and crossprotection to the original US PEDV infection. Veterinary Research, 46, 134.

Lin, C. M., Hou, Y., Marthaler, D. G., Gao, X., Liu, X., Zheng, L., Saif, L. J., \& Wang, Q. (2017). Attenuation of an original US porcine epidemic diarrhea virus strain PC22A via serial cell culture passage. Veterinary Microbiology, 201, 62-71.

Marthaler, D., Jiang, Y., Collins, J., \& Rossow, K. (2014). Complete genome sequence of strain SDCV/USA/Illinois121/2014, a porcine deltacoronavirus from the United States. Genome Announc, 2(2), e00218-14.

Masiuk, D. M., Sosnitsky, O. I., Nedzvetsky, V. S., Kokarev, A. V., \& Koliada, S. G. (2017). Endemic course of epidemic diarrhea of pigs in the stabilized focus of infection. Regulatory Mechanisms in Biosystems, 8(3), 410-416.
Okda, F., Liu, X., Singrey, A., Clement, T., Nelson, J., Christopher-Hennings, J., Nelson, E. A., \& Lawson, S. (2015). Development of an indirect ELISA, blocking ELISA, fluorescent microsphere immunoassay and fluorescent focus neutralization assay for serologic evaluation of exposure to North American strains of porcine epidemic diarrhea virus. BMC Veterinary Research, 11, 180.

Pan, Y., Tian, X., Li, W., Zhou, Q., Wang, D., Bi, Y., Chen, F., \& Song, Y. (2012). Isolation and characterization of a variant porcine epidemic diarrhea virus in China. Virology Journal, 9, 195.

Song, D., \& Park, B. (2012). Porcine epidemic diarrhea virus, a comprehensive review of molecular epidemiology, diagnosis and vaccines. Virus Genes, 44, $167-175$.

Song, D., Moon, H., \& Kang, B. (2015). Porcine epidemic diarrhea: A review of current epidemiology and available vaccines. Clinical and Experimental Vaccine Research, 4(2), 166-176.

Stadler, J., Zoels, S., Fux, R., Hanke, D., Pohlmann, A., Blome, S., Weissenböck, H., Weissenbacher-Lang, C., Ritzmann, M., \& Ladinig, A. (2015). Emergence of porcine epidemic diarrhea virus in southem Germany. BMC Veterinary Research, 11, 142.

Stevenson, G. W., Hoang, H., Schwartz, K. J., Burrough, E. R., Sun, D., Madson, D., Cooper, V. L., Pillatzki, A., Gauger, P., Schmitt, B. J., Koster, L. G., Killian, M. L., \& Yoon, K. J. (2013). Emergence of Porcine epidemic diarrhea virus in the United States: Clinical signs, lesions, and viral genomic sequences. Journal of Veterinary Diagnostic Investigation, 25, 649-654.

Sun, D., Wang, X., Wei, S., Chen, J., \& Feng, L. (2016). Epidemiology and vaccine of porcine epidemic diarrhea virus in China: A mini-review. Journal of Veterinary Medical Science, 78(3), 355-363.

Vlasova, A. N., Marthaler, D., Wang, Q., Culhane, M. R., Rossow, K. D., Rovira, A., Collins, J., \& Saif, L. J. (2013). Distinct characteristics and complex evolution of PEDV strains, North America, Emerging Infectious Diseases, 20(10), 1620-1628.

Wang, L., Byrum, B., \& Zhang, Y. (2014). New variant of porcine epidemic diarrhea virus, United States, 2014. The Journal of Veterinary Medical Science, 20, 917-919.

Wicht, O., Li, W., Willems, L., Meuleman, T. J., Wubbolts, R. W., van Kuppeveld, F. J. M., Rottier, P. J. M., \& Bosch, B. J. (2014). Proteolytic activation of the porcine epidemic diarrhea coronavirus spike fusion protein by trypsin in cell culture. Journal of Virology, 88, 7952-7961. 